\title{
Cultivar Registration at the Arnold Arboretum 1990
}

\author{
Stephen A. Spongberg ${ }^{1}$ \\ The Arnold Arboretum, 125 The Arborway, Jamaica Plain, MA 02130, USA
}

The Arnold Arboretum of Harvard University continues to serve as International Registration Authority for cultivar names in 11 genera of ornamental woody plants, and the following notes pertain to cultivar names that have been registered at the Arboretum since the last list was prepared. The 11 genera include Chaenomeles, Cornus, Fagus, Forsythia, Gleditsia, Lantana, Malus (ornamental species), Philadelphus, Pieris, Ulmus, and Weigela. Inquiries concerning the registration of cultivar names in these genera should continue to be addressed to Dr. S.A. Spongberg, The Arnold Arboretum, The Arborway, Jamaica Plain, MA 02130, USA.

Cultivar names registered during 1990 comprise the following three elms, all registered by Alden M. Townsend Research Geneticist, U.S. National Arboretum, 3501 New York Avenue, NE, Washington, District of Columbia 20002, USA.

Ulmus wilsoniana 'Prospector'. Registered 12 July 1990. 'Prospector' has a vase-shaped crown similar to that of the American elm, but it becomes pendulous at a much lower height. It averages $7 \mathrm{~m}$ tall with a crown spread of $6.4 \mathrm{~m}$ after 10 years of growth under nursery conditions. Its leaves average $11.4 \mathrm{~cm}$ long by $8.3 \mathrm{~cm}$ wide and are oblong-ovate in outline. As they expand from the buds in spring, they display an orangish-red color, but gradually darken to green. In re-

${ }^{1}$ Horticulturist Taxonomist, The Arnold Arboretum. search studies 'Prospector' has shown a high level of resistance to Dutch elm disease and the elm leaf beetle. The tree, grown under USNA \#55398, is hardy in USDA Zones 4-7, and tolerates a wide variety of soil conditions. The tree was originated at the Research Site of the U.S. National Arboretum in Delaware, Ohio, and was introduced commercially in 1990.

Ulmus 'Frontier' (U. carpinifolia $\times$ parviflora). Registered 12 July 1990. Ulmus 'Frontier' represents the first release of an elm cultivar with a parentage that combines a spring- and a fall-flowering species. It has demonstrated a high level of resistance to Dutch elm disease and moderate resistance to the elm leaf beetle. The tree develops a pyramidal crown, and the leaves average $5.4 \mathrm{~cm}$ long and $3.2 \mathrm{~cm}$ wide. Young leaves are red, becoming green, but in fall they turn reddishpurple. 'Frontier' exhibits a faster growth rate than U. parviflora, the male parent, and is hardy to USDA Zone 5. Commercial introduction is planned for early 1991.

Ulmus parviflora 'Pathfinder'. Registered 26 Sept. 1990. Ulmus 'Pathfinder' is vase-shaped in habit with a height of $11.3 \mathrm{~m}$ and a crown spread of $9.7 \mathrm{~m}$ at 27 years of age. The leaves turn a distinctive brilliant red in fall, and the tree is resistant to both Dutch elm disease and elm leaf beetle. Grown under USNA \#55345, 'Pathfinder' originated at the Ohio Research Site, U.S. National Arboretum, Delaware, Ohio, and is hardy into USDA Zone 5a. It is planned that 'Pathfinder' will be introduced commercially in 1991. 